- DOI: $10.31866 / 2410-1311.36 .2020 .221042$

Удк 008:316.774:654.1

\title{
- МЕДІАКУЛЬТУРА: СУТНІСНІ ОСОБЛИВОСТІ І ФУНКЦІЇ
}

\section{- Лисинюк Марина Віталіївна}

- Доктор фрілософрії (культурологія), ORCID: 0000-0002-0870-2176, e-mail: marina_lysynuk@ukr.net, Київський національний університет культури і мистецтв, вул. Є. Коновальця, 36, Київ, Україна, 01133

\section{- Для цитування:}

Лисинюк, М.В. (2020). Медіакультура: сутнісні особливості і фуннкції. Питання культурології, (36), 38-48. doi: https://doi.org/10.31866/2410-1311.36.2020.221042.

\section{- Анотація}

Мета статті - розкрити сутнісні особливості та функції медіакультури. Розвиток сучасного суспільства нерозривно пов'язаний 3 інфооммаційно-комунікаційними технологіями, тому актуальним $є$ визначення сутнісних особливостей і специфічних ознак медіакультури. Методологія дослідження ґрунтується на застосуванні методу адаптивно-діяльнісної культурології в комплексі з міждисциплінарним підходом, що дало змогу розкрити сутність, функції та структуру медіакультури. Наукова новизна полягає в культурологічному дослідженні діалектики взаємодії та взаємовпливу медіакультури як феномена інформаційного суспільства і процесів інформатизації початку XXI ст. Висновки. Визначено, що стрижнем всієї медійної культури є екранна та аудіовізуальна культура, які часто конкурують між собою. Відзначено, що медійна культура як соціокультурний френомен може трактуватися в широкому (соціальне середовище, що активно комунікує за допомогою символічного обміну) і вузькому (механізм культурної діяльності, що актуально проявляється в кожному когнітивному акті) розумінні. Виокремлено функції медіакультури: інформативна, комунікативна, нормативна, релаксаційна, креативна, інтеграційна, посередницька. Доведено взаємозв'язок медіакультури з культурою в традиційному розумінні останньої, а також зв'язок і взаємозалежність з іншими системами реальності. Вказано на особливості функціонування медіакультури в сучасному інформаційному просторі, іï поліфункціональність, вплив на всі сфрери життєдіяльності, зокрема схарактеризовано негативні впливи досліджуваного феномена і їх наслідки. Зазначено, що основним механізмом формування та відтворення медіакультури $є$ медіаосвіта, яка повинна сприяти виявленню і реалізації творчого потенціалу особистості, виробленню аналітичного ставлення до явищ і фактів дійсності. Йдеться про формування «людини медіакультури», про актуалізацію антропологічної концепції медіакультури, що забезпечить спадкоємність традицій існування в культурі на рівні особистості.

Ключові слова: культура; медіакультура; інформаційне суспільство 


\section{- Вступ}

У сучасному суспільстві, розвиток якого нерозривно пов'язаний з інформаційно-комунікаційними технологіями, масштаби розповсюдження яких зростають у геометричній прогресії, кожен новий вид медіа вбудовується у нові умови світоустрою. Цей процес, своєю чергою, змінює усталені форми соціальних взаємодій, руйнує звички людства, і пов'язаний із феноменом медіакультури як чинником інформаційної цивілізації. Однак, чіткого розуміння цього явища не існує. Тож, розглядаючи феноменологію медіакультури, актуальним є визначення її сутнісних особливостей і специфічних ознак, що дасть можливість розкрити не лише її функції, а й розглянути як систему.

Сьогодні накопичено значну кількість наукових праць, літератури, публікацій з питань медіакультури. Дослідницька парадигма бере свій початок у 70-х роках XX ст. Ï̈̈ вивчали представники різних наукових напрямів, включаючи фрілософрів, педагогів, соціологів, мистецтвознавців і, звичайно ж, культурологів. Останнім часом саме в межах культурології осмислені різні аспекти функціонування медіакультури, підкреслений її найтісніший зв'язок із соціокультурними процесами сучасного суспільства тощо. Зокрема, теоретичні засади вивчення медіакультури та її роль у соціокультурному житті суспільства були закладені Г. Тардом (Tarde, 1969) та ін. У Західній Європі й США дослідження характеру та сутності мас-медіа здійснювали П. Лазарсфрельд (Lazarsfeld, 1975), Г. Лассуелл (Lasswell, 1948) та ін., значення масової комунікації в історії й культурі вивчали М. Маклюен (Маклюэн, 2004) і О. Тофрфлер (1999). Д. Мак-Квейлом (2010) медіакультура розглянута як комунікаційне явище, тісно пов'язане із сучасними соціокультурними процесами. Д. Келлнер (Kellner, 1995), Дж. Бігнелл (Bignell, 2001) та інші закордонні дослідники розглядають медіакультуру у зв'язку із соціальними трансформаціями, Н. Кирилова (Кириллова, 2005) та Н. Кумелашвілі (Кумелашвили, 2011) звертають увагу на історичний контекст, а також на естетичні проблеми медіакультури. В. Возчиков (2007), І. Єлінер (Елинер, 2010) та О. Пугач (2000) розглядають медіакультуру у контексті розвитку інформаційного суспільства. На взаємовпливі медіакультури й інформаційного суспільства наголошує Л. Ороховська (2015), комунікаційний підхід до вивчення медіакультури презентований у працях Г. Почепцова (2013). Розвитку медіаосвіти і медіапсихології присвячені дослідження Л. Найдьонової (2007).

Попри те, що окремі аспекти заявленої проблеми широко представлені в наукових працях українських і закордонних дослідників, все ж вивчення сутнісних особливостей і фрункцій медіакультури вимагає нових досліджень проявів медіакультури в сучасному суспільстві, виконаних в межах культурології.

\section{Мета статті}

Мета статті - розкрити сутнісні особливості і функції медіакультури. Методологія дослідження ґрунтується на застосуванні принципів адаптивно-діяльнісної культурології в комплексі з міждисциплінарним підходом, що дало змогу розкрити сутність, функції та структуру медіакультури. Наукова новизна полягає в культурологічному дослідженні діалектики взаємодії і взаємовпливу медіакультури як феномена інформаційного суспільства і процесів інформатизації на початку XXI ст. 


\section{- Виклад матеріалу дослідження}

Поява медійної культури видається цілком закономірним етапом культурноісторичного розвитку суспільства (Кумелашвили, 2011, с. 8). Медіа, медіальність поступово нарощували свою присутність у культурі, тривалий час посилювали свій вплив на соціокультурні процеси, допоки не стали домінуючими. Таку позицію медійна культура здобула внаслідок актуалізації в суспільстві проблеми інформатизації, диверсифрікації та інтенсифрікації останньої, що за часом збіглося з посиленням експансії екранних форм культури, комп'ютеризацією всіх сфер сучасного життя. Така інтенсифікація суспільних процесів вимагала не конвенціонально позначених форм інформації, які виникали при використанні друкованих текстів (слова, цифри), а конкретної, унікальної і документально достовірної інформації, що ґрунтується на можливостях зображення. Не випадково наприкінці 60-х - початку 70-х років минулого століття потужно заявило про себе телебачення як комунікативний засіб, що поєднав у собі інформаційну потужність слова і зображення, можливості візуальних (фотографрія), аудіальних (радіо, грамплатівки та ін.) та аудіовізуальних (кіно) текстів - текстів нового типу, які сьогодні звично називають медійними. Почалася ера домінування аудіовізуальної культури, або нових медіа - ТБ, відео, мультимедіа, інтернет. Подальшим каталізатором цього процесу став розвиток комп'ютерних технологій, які інтегрували в собі комунікативні можливості традиційних друкованих та нових медійних текстів. Мультимедійні та мережеві засоби комп'ютерних технологій зробили процес передачі інформації надзвичайно різноманітним, дієвим та при цьому оперативним і глобальним, завдяки віртуальності своїх повідомлень.

Враховуючи складність і масштабність медійної культури, ії осмислення повинно ґрунтуватися на певних положеннях, зокрема: 1) медійна культура - це домінуюча культура інформаційного суспільства, що забезпечує формування соціокультурної картини світу за допомогою різних образів, які генеруються традиційними та електронними засобами масової інформації; 2) це культурауніверсум, яка поєднала в собі народну, масову й елітарну культури та їх різновиди; 3) це метаповідомлення, де відображено світоглядний стан суспільства в різні періоди розвитку; 4) це знак дії, сила якого може бути скерована на маніпуляцію суспільною свідомістю або на розвиток людини, долучення її до кращих досягнень науки, культури, творчості; 5) це специфічний спосіб освоєння дійсності, що використовує різні знакові коди, який забезпечує найбільш адекватне відображення реальності (Возчиков, 2007, с. 10). При цьому стрижнем усієї медійної культури є екранна та аудіовізуальна культура, які досить часто конкурують між собою. Очевидно, що медійна та аудіовізуальна культури - нетотожні. Так, аудіовізуальна культура визначається як «сфера культури, пов'язана із поширеними сучасними технічними способами записування і передання зображення і звука (кіно, телебачення, відео, системи мультимедіа)» (Левит, 1998, с. 46). Медійна культура є ширшим поняттям, що охоплює і друковані, і аудійні, і візуальні, i аудіовізуальні інфрормаційно-комунікативні засоби разом із сучасними текстами.

Виходячи з цього, деякі дослідники визначають медіакультуру як «сукупність матеріальних та інтелектуальних цінностей у сфері медіа, а також історично 
визначена система їх відтворення та функціонування в соціумі; щодо аудиторії «медіакультура» може бути системою рівнів розвитку особистості людини, здатної сприймати, аналізувати, оцінювати медіатекст, займатися медіатворчістю, засвоювати нові знання в сфері медіа» (Фёдоров, 2004, с. 116). В цьому ракурсі важко не помітити, що зміст медіакультури тут розкривається через розуміння культури та її традиційне визначення. Такий підхід до дослідження без сумніву можливий: не можна розглядати медіакультуру, відсторонившись від культури як такої, адже більшістю дослідників відзначається, що медіакультура за своєю суттю не лише споріднена з культурою, а й є частиною її системи. Так, дослідник інформаційного суспільства Н. Коновалова (2004) розглядає медіакультуру як грань культури та уточнює її зв'язок з медіааспектом усіх видів життєдіяльності людей у суспільстві. Як специфічна галузь культури вона містить «культуру передання інформації і культуру її сприйняття; може бути і системою рівнів розвитку особистості, здатної сприймати, аналізувати, оцінювати той чи інший медіатекст, займатися медіатворчістю, засвоювати нові знання за допомогою медіа» (Кириллова, 2005, с. 5).

У загальних рисах медійна культура як соціокультурний феномен може трактуватися в широкому і вузькому розумінні. У широкому розумінні - це соціальне середовище, що активно комунікує за допомогою символічного обміну, який реалізує взаємодію між різними підсистемами суспільства. У вузькому розумінні медійна культура - це «механізм культурної діяльності, що актуально виявляється в кожному когнітивному акті, за допомогою медіальних і символічних форм реалізує внутрішні образні репрезентації, які відтворюють на сенсорному рівні об'єкти зовнішнього світу, і формує ті взаємозв'язки, в яких одиничне стає елементом цілісної системи, знаходячи фрорму впорядкованості в процесі духовного осягнення і тлумачення буття, формує сполучну тканину соціуму» (Кузнецова, 2010, с. 10-11).

Говорячи про особливості функціонування медіакультури, необхідно відзначити, що вчені виокремлюють такі ії функції:

- інформативна (культура сама по собі є носієм інформації, завдяки їй стає можливим накопичення і множення інформації, отож медіакультура - соціальна інформація, яка зберігається і накопичується в суспільстві за допомогою знакових засобів, створюваних людством) (Кириллова, 2005, с. 63);

- комунікативна (тісний зв'язок цієї фрункції з попередньою є зрозумілим; завдяки комунікативній функції відбувається обмін інфрормацією в різних контекстах);

- нормативна, або ідеологічна (медіакультура несе відповідальність за процес соціалізації особистості, засвоєння нею соціального досвіду, норм, знань, ідеалів, які відповідають певному суспільству);

- релаксаційна, або розважальна (пов'язана з потребами людини у відпочинку; медіакультура пропонує спеціальні засоби розслаблення: від комп'ютерних ігор до інтерактивних видовищ ТБ);

- креативна (дає можливість для освоєння і перетворення світу, навколишнього життя, задовольнити власну допитливість в якій-небудь сфері; за допомогою інформації людина отримує знання й осмислює їх); 
- інтеграційна (культура сприяє об'єднанню одного народу, вона зберігає все, що накопичено державою, створює зв'язок між поколіннями);

- посередницька (медіакультура є соціальним посередником, який встановлює зв'язок між структурами суспільства).

Таким чином, аналізуючи сукупність визначень поняття медіакультури та особливості її функціонування, стають помітними аналогії у визначенні поняття медіакультури, що, так чи інакше, трактується як тип або підсистема культури інформаційного суспільства. Безсумнівно, сучасна медійна культура являє собою системне ціле, глибоко вкорінене в соціальне середовище, яке сформувало свій медійний простір, що функціонує на основі знакового, символіко-медійного обміну. Серед ії компонентів дослідники виокремлюють: матеріальний і духовний компоненти, творчі сили і здібності людини (Айгина, 1993, с. 7); когнітивний (сукупність знань та уявлень про інформаційну картину світу), операційнотехнологічний (сукупність алгоритмів людської діяльності, пов'язаної з обробкою інформації), психофізичний (сукупність певних психічних структур і загальних здібностей, необхідних для реалізації алгоритмів інформаційної діяльності) та аксіологічний (система ціннісних орієнтацій, етичних і моральних норм) компоненти (Пугач, 2000, с. 82). Подібне структурування медіакультури, по суті, виокремлює однакові елементи медіакультури, тільки різною термінологічною мовою - це сукупність міждисциплінарних знань, норм спілкування і відносини зі світом, певні вміння і навички особистості, досвід творчо-пошукової діяльності.

Розгляд медіакультури як одного із найважливіших аспектів культурної діяльності загалом дає дослідникам можливість розглядати її не просто як підсистему культури, а як складну ієрархічно розвинену систему, яка з морфологічної точки зору складається з різних рівнів, на кожному з яких відповідно до системного підходу можуть бути виявлені вужчі системи - підсистеми медіакультури (Кузнецова, 2010). Більш складним рівнем є рівень символічних форм, де можуть бути виокремлені підсистеми комунікативних засобів. Універсальною системою тут постає природна мова, а також невербальні за своїм характером мови - жестів, іконічні системи, оскільки вони являють собою сукупність елементів, що перебувають у багатовимірних відносинах один із одним й утворюють певну цілісну єдність, здатну функціонувати. Рівень символічної реальності - синтетичний рівень, на якому можуть бути виявлені складніші категорії, такі, як естетична реальність, медіареальність, віртуальна реальність. У цьому аспекті медіакультура як більш широка система може позиціонуватися як середовище для всіх підсистем, що виокремлюються на перерахованих структурних рівнях. Сама ж медіакультура є підсистемою культури як однієї із систем соціального середовища, яка у взаємному обміні з нею проявляє свої специфічні функції (Кузнецова, 2010).

Дослідник мультимедійної системи в галузі культурології І. Єлінер зазначає, що структура системи медіа досить непроста, оскільки в її зміст входить радіо-, кіно-, телевізійні і комп'ютерні канали та глобальні інформаційні мережі, що володіють величезною цільовою аудиторією і силою впливу на неї. Називаючи вищеописані структурні одиниці медіа, вчений наголошує, що система містить елементи, якими є конкретна ТБ-програма, web-сайт тощо. Включення в неї 
групи різнорідних ТБ-програм i web-сайтів, що працюють на одну функцію (пізнавальну, розважальну, освітню), створює конгломерат системи. Блоком, виходячи з вищесказаного, є ТБ-канали, невеликі локальні, регіональні провайдери, взаємопов'язані один із одним і здатні підпорядкувати собі інші елементи і конгломерати (Елинер, 2010, с. 15).

Отже, медіакультурі притаманне використання продуктів медіа в будь-якій сфері життєдіяльності, відсутність територіальних кордонів, одночасний синтез звукового, візуального, вербального, навіть, в сучасних медіа, запаху та смаку, формування принципово іншого типу мислення, а також інтерактивного сприйняття інформації та принципово інші взаємини автора і читача, виробника і споживача. При цьому життєдіяльність медіакультури, як і будь-якої іншої системи, неможливо розглядати відсторонено від інших систем, не враховуючи їх постійної взаємодії. Медіакультура нерозривно пов'язана з суспільством, культурою, мистецтвом та іншими системами існуючих реалій, тому закономірно, що медіакультура формує і світогляд, і побутову поведінку людини, прищеплює їй певні стандарти, моду і мовну практику, що не завжди має позитивні наслідки.

\section{- Висновки}

Таким чином, медійна культура - соціокультурний феномен, який є соціальним середовищем, що активно комунікує за допомогою символічного обміну, реалізовуючи взаємодію між підсистемами суспільства та як механізм культурної діяльності. Вона ґрунтується на таких положеннях: домінуюча культура інформаційного суспільства, що забезпечує формування соціокультурної картини світу; культура-універсум, яка поєднала в собі народну, масову й елітарну культури та їх різновиди; метаповідомлення, в якому відображено світоглядний стан суспільства; знак дії, що може бути скерована як на маніпуляцію суспільною свідомістю, так і на розвиток людини; специфічний спосіб освоєння дійсності. При цьому, зміст медіакультури розкривається через розуміння культури та її традиційне визначення.

Наголошено, що поняття медіакультури трактується як тип або підсистема культури інформаційного суспільства, функціями якої є: інформативна; комунікативна; нормативна, або ідеологічна; релаксаційна, або розважальна; креативна; інтеграційна; посередницька. Медіакультурі притаманне використання продуктів медіа в будь-якій сфері життєдіяльності, відсутність територіальних кордонів, одночасний синтез сприйняття усіма органами чуття, фрормування принципово іншого типу мислення, інтерактивного сприйняття та принципово інші взаємини автора і читача, виробника і споживача.

Водночас медіакультура, формуючи світогляд та побутову поведінку людини, прищеплює їй певні стандарти, моду і мовну практику, що не завжди має позитивні наслідки. Тому, для подальшого розвитку суспільства необхідні цілеспрямовані дії з формування медіаосвіти, яка повинна сприяти виявленню і реалізації творчого потенціалу особистості, виробленню аналітичного ставлення до явищ і фрактів дійсності. Тобто йдеться про формування «людини медіакультури», про актуалізацію антропологічної концепції медіакультури, що забезпечує, перш за все, спадкоємність традицій існування в культурі на рівні особистості. 
При масштабному розвитку медіакультури можливі прояви однобокості, пов'язані з агресією мовлення, пасивною адаптацією і засобом створення нових негативних явищ та ін. Однак ці питання потребують окремого дослідження.

\section{- Список використаних джерел}

Айгина, Т. Е. (1993). Комплексный подход к воспитанию инфрормационной культуры старших школьников [Автореферат диссертации кандидата педагогических наук, Бишкек].

Возчиков, В. А. (2007). Философрия образования и медиакультура информационного общества [Автореферат диссертации доктора философских наук, Российский государственный педагогический университет им. А.И. Герцена].

Елинер, И. Г. (2010). Развитие мультимедийной культуры в информационном обществе [Авторефрерат диссертации доктора культурологии, СанктПетербургский государственный университет культуры и искусств].

Кириллова, Н. Б. (2005). Медиакультура как интегратор среды социальной модернизации [Диссертация доктора культурологии, Российский институт культурологии].

Коновалова, Н. А. (2004). Развитие медиакультуры студентов педагогического вуза [Диссертация кандидата педагогических наук, Вологодский государственный педагогический университет].

Кузнецова, Е.И. (2010). Медиальность и медиакультура как фракторы динамики социальной среды [Автореферат диссертации доктора философских наук, Нижегородский государственный университет им. Н. А. Добролюбова].

Кумелашвили, Н. У. (2011). История медиакультуры: самоопределение от древности до Нового времени. Культура и цивилизация, 1, 8-26.

Левит, С. Я. (Ред.) (1998). Культурология XX век. Энциклопедия. Университетская книга.

Мак-Квейл, Д. (2010). Теорія масової комунікації (О. Возьна, Г. Сташків, Пер.). Літопис.

Маклюэн, М. (2004). Средство само есть содержание. В Инфрормационное общество (c. 341-348). ACT.

Найдьонова, Л.А. (2007). Перспективи розвитку медіаосвіти в контексті болонського процесу: процесуальна модель медіа культури. В Болонський процес $і$ вища освіта в Україні та Європі: проблеми й перспективи (с. 162-168).

Ороховська, Л.А.(2015). Медіакультура у дзеркалі фрілософііі історії [Монографія]. Центродрук.

Почепцов, Г. (2013). Мерлин, Супермен и Гарри Поттер: конструирование нематериального в массовой культуре. Спадщина.

Пугач, О.И. (2000). Формирование информационной культуры учащихся общеобразовательных школ как фрактор гуманизации образования [Диссертация кандидата педагогических наук, Самарский университет].

Тоффрлер, Э. (1999). Третья волна. АСТ.

Фёдоров, А. В. (2004). Медиаобразование и медиаграмотность. Кучма.

Bignell, J. (2001). Postmodern Media Culture. Edinburg University Press.

Kellner, D. (1995). Media Culture: Cultural Studies, Identity and Politics Between the Modern and Postmodern. Routledge. https://doi.org/10.1177/000169939603900213. 
Lasswell, H. D. (1948). The Structure and Function of Communication in Society. In L. Bryson (Ed.), The Communication of Ideas. The Institute for Religious and Social Studies. http:// www.twirpx.com/file/365721/.

Lazarsfeld, P. F., \& Merton, R. K. (1975). Mass Communication, Popular Taste and Organized Social Action. In W. Schramm (Ed.), Mass Communications (pp. 229-250). University of Illinois Press.

Tarde, G. (1969). On Communication and Social Influence: Selected Papers. University of Chicago Press.

\section{References}

Aigina, T. E. (1993). Kompleksnyi podkhod k vospitaniyu informatsionnoi kul'tury starshikh shkol'nikov [An integrated approach to the education of the information culture of senior schoolchildren] [Abstract of PhD Dissertation, Bishkek] [in Russian].

Bignell, J. (2001). Postmodern Media Culture. Edinburg University Press [in English].

Eliner, I. G. (2010). Razvitie mul'timediinoi kul'tury $v$ informatsionnom obshchestve [Development of multimedia culture in the information society] [Abstract of DSc Dissertation, Sankt-Peterburgskii gosudarstvennyi universitet kul'tury i iskusstv] [in Russian].

Fedorov, A. V. (2004). Mediaobrazovanie i mediagramotnost' [Media Education and Media Literacy]. Kuchma [in Russian].

Kellner, D. (1995). Media Culture: Cultural Studies, Identity and Politics Between the Modern and Postmodern. Routledge. https://doi.org/10.1177/000169939603900213 [in English].

Kirillova, N. B. (2005). Mediakul'tura kak integrator sredy sotsial'noi modernizatsii [Media culture as an integrator of the social modernization environment] [Doctoral Dissertation, Rossiiskii institut kul'turologii] [in Russian].

Konovalova, N. A. (2004). Razvitie mediakul'tury studentov pedagogicheskogo vuza [Development of media culture of students of Pedagogical Higher Education Institution] [PhD Dissertation, Vologodskii gosudarstvennyi pedagogicheskii universitet] [in Russian].

Kumelashvili, N. U. (2011). Istoriya mediakul'tury: samoopredelenie ot drevnosti do Novogo vremeni [The history of media culture: self-determination from antiquity to modern times]. Kul'tura i tsivilizatsiya, 1, 8-26 [in Russian].

Kuznetsova, E. I. (2010). Medial'nost' i mediakul'tura kak faktory dinamiki sotsial'noi sredy [Mediality and media culture as factors of the dynamics of the social environment] [Abstract of DSc Dissertation, Nizhegorodskii gosudarstvennyi universitet im. N. A. Dobrolyubova] [in Russian].

Lasswell, H. D. (1948). The Structure and Function of Communication in Society. In L. Bryson (Ed.), The Communication of Ideas. The Institute for Religious and Social Studies. http:// www.twirpx.com/file/365721/ [in English].

Lazarsfeld, P. F., \& Merton, R. K. (1975). Mass Communication, Popular Taste and Organized Social Action. In W. Schramm (Ed.), Mass Communications (pp. 229-250). University of Illinois Press [in English].

Levit, S. Ya. (Ed.). (1998). Kul'turologiya XX vek [Cultural studies of the 20 $0^{\text {th }}$ century] [Encyclopedia]. Universitetskaya kniga [in Russian]. 
McLuhan, H. M. (2004). Sredstvo samo est' soderzhanie [The Medium is the Message]. In Informatsionnoe obshchestvo [Information society] (pp. 341-348). ACT [in Russian]. McQuail, D. (2010). Teoriia masovoi komunikatsii [Theory of mass communication] (O. Vozna, H. Stashkiv, Trans.). Litopys [in Ukrainian].

Naidonova, L. A. (2007). Perspektyvy rozvytku mediaosvity v konteksti bolonskoho protsesu: protsesualna model media kultury [Prospects for the development of media education in the context of the Bologna process: a procedural model of media culture]. In Bolonskyi protses $i$ vyshcha osvita $v$ Ukraini ta Yevropi: problemy y perspektyvy [The Bologna Process and Higher Education in Ukraine and Europe: Problems and Prospects] (pp. 162-168) [in Ukrainian].

Orokhovska, L. A. (2015). Mediakultura u dzerkali filosofii istorii [Media culture in the mirror of the philosophy of history] [Monohraph]. Tsentrodruk [in Ukrainian].

Pocheptsov, G. (2013). Merlin, Supermen i Garri Potter: konstruirovanie nematerial'nogo $v$ massovoi kul'ture [Merlin, Superman and Harry Potter: the construction of the intangible in popular culture]. Spadshchina [in Russian].

Pugach, O. I. (2000). Formirovanie informatsionnoi kul'tury uchashchikhsya obshcheobrazovatel'nykh shkol kak faktor gumanizatsii obrazovaniya [Formation of information culture of students of secondary schools as a factor in the humanization of education] [PhD Dissertation, Samarskii universitet] [in Russian].

Tarde, G. (1969). On Communication and Social Influence: Selected Papers. University of Chicago Press [in English].

Toffler, A. (1999). Tret'ya volna [Third Wave]. AST [in Russian].

Vozchikov, V. A. (2007). Filosofiya obrazovaniya i mediakul'tura informatsionnogo obshchestva [Philosophy of Education and Media Culture of the Information Society] [Abstract of DSc Dissertation, Rossiiskii gosudarstvennyi pedagogicheskii universitet im. A.I. Gertsena] [in Russian].

\section{- MEDIA CULTURE: ESSENTIAL FEATURES AND FUNCTIONS}

\section{Maryna Lysyniuk}

PhD in Cultural Studies, ORCID: 0000-0002-0870-2176, e-mail: marina_lysynuk@ukr.net, Kyiv National University of Culture and Arts, Kyiv, Ukraine

\section{Abstract}

The purpose of the article is to reveal the essential features and functions of media culture. The development of modern society is closely connected with information and communication technologies, therefore, it is relevant to determine the essential and special features of media culture. The research methodology is based on the application of the method of adaptiveactivity cultural studies in combination with an interdisciplinary approach, which allowed us to reveal the essence, functions and structure of media culture. The scientific novelty lies in the cultural studies research of the dialectic of interaction and mutual influence of media culture as 
a phenomenon of the information society and the processes of informatization at the beginning of the $21^{\text {st }}$ century. Conclusions. The article has demonstrated that the core of the entire media culture is the screen and audiovisual culture, which often compete with each other. It has been noted that media culture as a sociocultural phenomenon can be interpreted in a broad (the social environment that actively communicates through the symbolic exchange) and a narrow (the mechanism of cultural activity that is relevant in every cognitive act) sense. The author of the article has outlined the functions of media culture: informative, communicative, normative, relaxation, creative, integration, mediatory. The relationship of media culture with culture in its traditional sense, as well as the connection and interdependence with other systems of reality, has been proved. The peculiarities of the functioning of media culture in the modern information space, its multifunctionality, impact on all spheres of life, in particular, the individual negative influences of the studied phenomenon and their causality have been indicated. The article has shown that the main mechanism of formation and reproduction of media culture is media education, which should contribute to the identification and realization of the creative potential of the individual, the development of an analytical attitude to the phenomena and facts of reality. The article deals with the formation of a "person of media culture", the actualization of the anthropological concept of media culture, which will ensure the continuity of traditions of existence in culture at the individual level.

Keywords: culture; media culture; information society

\title{
МЕДИАКУЛЬТУРА: СУЩНОСТНЫЕ ОСОБЕННОСТИ И ФУНКЦИИ
}

\author{
Лисинюк Марина Витальевна \\ - Доктор философфии (культурология), \\ ORCID: 0000-0002-0870-2176, e-mail: marina_lysynuk@ukr.net, \\ Киевский национальный университет культуры и искусств, \\ Киев, Украина
}

\section{Аннотация}

Цель статьи - раскрыть сущностные особенности и функции медиакультуры. Развитие современного общества неразрывно связано с информационно-коммуникационными технологиями, поэтому актуальным является определение сущностных особенностей и специфических признаков медиакультуры. Методология исследования основана на применении метода адаптивно-деятельностной культурологии в комплексе c междисциплинарным подходом, что позволило раскрыть сущность, функции и структуру медиакультуры. Научная новизна заключается в культурологическом исследовании диалектики взаимодействия и взаимовлияния медиакультуры как феномена информационного общества и процессов информатизации начала XXI века. Выводы. Определено, что стержнем всей медийной культуры является экранная и аудиовизуальная культура, которые зачастую конкурируют между собой. Отмечено, что медийная культура как социокультурный феномен может трактоваться в широком (социальная среда, 
которая активно коммуницирует с помощью символического обмена) и узком (механизм культурной деятельности, который актуально проявляется в каждом когнитивном акте) понимании. Выделены функции медиакультуры: информативная, коммуникативная, нормативная, релаксационная, креативная, интеграционная, посредническая. Доказана взаимосвязь медиакультуры с культурой в традиционном понимании последней, а также связь и взаимозависимость с другими системами реальности. Указано на особенности функционирования медиакультуры в современном информационном пространстве, ее полифункциональность, влияние на все сферы жизнедеятельности, в частности охарактеризованы негативные влияния исследуемого феномена и их последствия. Отмечено, что основным механизмом формирования и воспроизводства медиакультуры является медиаобразование, которое должно способствовать выявлению и реализации творческого потенциала личности, выработке аналитического отношения к явлениям и фрактам действительности. Речь идет о формировании «человека медиакультуры», об актуализации антропологической концепции медиакультуры, что обеспечит преемственность традиций существования в культуре на уровне личности.

Ключевые слова: культура; медиакультура; информационное общество 